DOI: $10.17805 /$ trudy.2016.6.10

\title{
АВТОРИТЕТ УЧИТЕЛЯ В КИТАЙСКОЙ КУЛЬТУРНОЙ ТРАДИЦИИ
}

\author{
О. А. Санникова \\ (Московский гуманитарный университет)
}

Аннотация: В статье рассматривается феномен авторитета учителя, на основе анализе китайской литературы ХХ века.

Ключевые слова: Китай; Конфуций; культура Китая; педагогика Китая; культурная революция; литература Китая

\section{THE AUTHORITY OF TEACHERS IN CHINESE CULTURAL TRADITIONS}

\author{
O. A. Sannikova \\ (Moscow University for the Humanities)
}

Abstract: The article deals with the phenomenon of teacher authority on Chinese literature analysis of the XX century.

Keywords: China; Confucius; culture of China; Pedagogy of China; cultural revolution the Department; Literature of China

Уровень влияния учителя на ученика, успех его педагогической деятельности, прежде всего, зависит от авторитета, который учитель достиг перед своими учениками. По мнению С. С. Чабановой, авторитет учителя представляет собой интегративную характеристику его личности, приобретаемую в процессе деятельности и общения с учащимися, которая основывается на обладании учителем рядом свойств, качеств, заслуг, знаний и опыта, получивших широкое признание, что проявляется в доверии, признании за носителем авторитета права на руководство, следовании его указаниям и советам (Чабанова, 2011). В течение периода обучения между педагогом и учениками формируются отношения особой категории. Важным считается внимание взрослого к проявлению своеобразия каждого ученика. Рассмотрим особенности отношений учителя и ученика в китайской педагогической традиции. 
В Китае отношения между учителем и учениками со временем были подвержены существенным изменениям. В древние времена ученики относились к учителю с бесконечным почитанием и трепетом, признавали значимость авторитета педагога, и выражали уважение к его возрасту. Тем не менее, постепенно такие отношения были подвержены резкому уравниванию, в этот период в отношениях ученика и педагога появился диалог, и предпринимались попытки совместными усилиями найти истину. В период свершения культурной революции уважительное отношение к вчерашним учителям сменилось на ненависть, презрение и жестокость.

Необходимо подчеркнуть, что преобразование отношений произошло не единовременно, а легкими поступательными движениями, не существовало также определенной точки перелома, в которой данные преобразования были совершены. Видоизменение отношений происходило в течение продолжительного периода времени. И основная причина продолжительности этого процесса сводится к тому что, постепенно трансформировалось и само понятие «образование». Соответственно, каноны конфуцианства с течением времени были подвержены абсолютным искажениям, с целью подстроить их под новые жизненные условия, таким образом, идея Конфуция об образовании была абсолютно изменена. В дальнейшем это привело к более отчетливому проявлению непонимания между учителем и его учениками.

В китайском языке обращение к человеку, который пользуется авторитетом, звучит как «лаоши»- учитель, хотя к педагогике этот человек может не иметь никакого отношения.

Мысли Конфуция дошли до современников в составленных его учениками и последователями книгах «Луньюй» («Беседы и суждения»), в летописи «Чуньцю» («Весна и осень»), исторических записках «Шицзин». Свой главный труд «Шесть канонов», из которых не сохранился канон о музыке, он пишет, когда ему исполнилось 68 лет. Эти каноны легли в основу литературной традиции китайской культуры. Традиции, обычаи, манеру общения и поведения китайцев, все то, что иногда называют «китайскими церемониями», веками шлифовало это учение. И первым учебником китайского малыша были изречения Учителя, порой не совсем понятные, но через призму которых он начинал смотреть на окружающий мир.

Но со временем, ситуация изменилась, вместо формирования природных талантов, о чем говорил Конфуций, учитель заставлял своих подопечных выучивать наизусть канонические тексты, абсолютно игнорируя интересы и способности каждого отдельного ученика. Тем самым ученики же нередко воспринимали образование не как культурное обогащение, а как путь к сдаче государственных экзаменов, и, как следствие, получение должности. Однако, в дальнейшем ситуация все больше и больше 
усугублялась.

Анализируя образование в Китае XX века, можно с уверенностью утверждать, что исследованием данной категории было заинтересовано множество писателей этой страны. Как правило, они освещали данные вопросы в своем творчестве. В качестве примера можно привести творчество Е. Шэнтао (Е. Шаоцзюнь, 1894-1988), постигшего на собственном примере все тяготы ученичества. После того как Шэнтао повзрослел и сам стал учителем, ему удалось исследовать эту проблему изнутри. Он определил, что преподаватели довольно часто видят свою работу лишь с позиции принятия ее только как средства к существованию. Именно по этой причине учителя могут не стремиться к тому, чтобы найти индивидуальный подход к каждому ученику, мало заинтересованы в познании внутреннего мира ребенка. Ко всему прочему государство также недостаточно уделяло внимания вопросам образования, и по этой причине не было разработано интересной образовательной программы для детей. Под образованием в то время подразумевалась зубрежка канонических текстов, как в древние времена.

В 1925 г. Е. Шэнтао заканчивает написание своего романа «Учитель Ни Хуаньчжи». Основной темой романа является дорога интеллигента в революцию: действие повествования происходит в период заката империи Цинь (первое 10-летие XX века), а главный герой его - молодой человек Ни Хуаньчжи. После того как герой получает образование он стремиться к тому чтобы нести образование в массы, обучать простой народ. Искренняя вера юноши заключается в том, что он убежден - спасение Китая зависит от просвещенного человека. Помимо этого Ни Хуаньчжи находит своего единомышленника, в лице директора школы, в которую попадает главный герой. Этим учителем был Цзян Бинчжу. Совместными усилиями они предпринимают попытку воспитать новое поколение людей, отличающихся образованностью и повышенным интересом ко всему происходящему. Со временем они понимают, что их усилия были напрасны: ученики не разделяют идеалы своих педагогов, а лица наделенные властью в этой деревне активно протестуют против каких-либо изменений в образовании, так как им это не выгодно. В итоге, с течением времени, Ни Хуаньчжи принимает решение бросить все и сломить устои старого общества: он перебирается в Шанхай и вступает в ряды активных участников революции.

Небольшой рассказ «Урок» Е. Шэнтао повествует читателю ситуацию, в которой ребенок оказался намного ближе к научной деятельности и к реальности, чем его педагог. На уроке естествознания мальчик спрятал под партой коробок, в нем живет несколько тутовых червячков. Мальчик подкладывает в коробок несколько тутовых листочков для того что- 
бы червячкам было чем питаться. В ходе урока преподаватель в скучной и монотонной манере повествует какие-то факты о естествознании, но мальчик не вслушивается в то, что рассказывает педагог, потому что живая природа для него в этот момент сосредоточена в его коробке с тутовыми червячками. Таким образом, Е. Шэнтао доводит до читателя мысль о том, что маленький ученик порой намного более близок к естествознанию и природе, нежели его педагог.

Таким образом, можно отметить, что Е. Шэнтао является суровым реалистом, но в своих рассказах он не дает каких-либо оценок, читатель, в процессе ознакомления с его работами должен сам сделать выводы (История Китая, 2002).

Одним из наиболее трудных этапов развития китайской литературы можно назвать культурную революцию (1965-1976 гг.). Государственная политика в тот период была нацелена на уничтожение традиционализма и обострение конфликта между поколениями. В этот период интеллигенция Китая подвергалась гонениям и репрессиям. Ранее бесспорно уважаемый статус «учитель» в то время стал своего рода клеймом. Таким образом, ученики перестали уважительно относиться к своим учителям, стали подвергать их издевкам и унижениям. Фен Цзицай в своей работе «На тропинках усыпанных цветами» повествует рассказ о том, как ученики школы на митинге забивают свою учительницу, отказавшуюся признать свою вину перед партией, а также принять идеологию, навязанную Культурной революцией.

Впоследствии, после того как культурная революция закончилась, а также умер вождь Мао, лидеры партии стали двигаться по направлению экономического развития страны. В этот же момент принимаются первые попытки развития системы образования в государстве. Прежде всего, этот было обусловлено острой необходимостью научно-технического прогресса в стране, который могли обеспечить лишь высококвалифицированные кадры. Таким образом, в начале 80 -х годов правительством Китая принимается ряд законов об образовании, а также проводится достаточно серьезная реформа образования. По причине нехватки преподавателей была запущена целая программа поддержки педагогов. Помимо этого, молодых учителей стали направлять на работу в провинцию, так как там наиболее остро ощущался недостаток профессионалов (там же).

Структура взаимоотношений между учителем и его учениками также непрерывно изменялась в тот период. Притом, что культурная революция уже была окончена, и педагогам удалось восстановить свой статус, но отношение к ним осталось таким же, каким было во время революции. Нельзя утверждать, что учителей теперь меньше уважают. Вовсе нет. Но теперь стали возникать такие ситуации, о которых в Имперском Китае 
нельзя теперь и помыслить.

В частности, рассказ «Внутренняя сущность» Ма Сяошоу также повествует о сложных отношениях учителя с его учениками. Между собой ученики учителя Ма Сяошоу называли его «маленькая худая лошадка» так как он был очень маленького роста, а также отличался болезненной худобой «как ветка дерева зимой с севера». Ученики считали это прозвище хитроумным, и через некоторое время так стали называть своего учителя даже девочки. В один момент учителю становится известно об этой шутке. Он не был разозлен, а скорее ему стало грустно, и учитель изрек, что такие таланты принесли бы намного больше пользы в учебе. Однажды учитель устраивает своим ученикам опрос по пройденным материалам, ни один ученик не смог ничего рассказать. И что было абсолютно неожиданным для учеников, учитель вдруг расплакался. Слезы градом катились по щекам учителя, тело в беспомощной позе замерло у школьной доски. Единственную фразу в тот момент сказал детям учитель о том, что они должны впредь хорошо учиться и покинул кабинет. С той поры ученики стали относиться к учебе с усердием, и тщательно изучали предмет учителя, но тот больше ни разу не спросил, ни о чем, ни одного ученика. С течением времени, после того как рассказчик стал взрослым, этот опыт не раз пригождался ему на жизненном пути. Прочитав этот рассказ, можно с уверенностью утверждать, что настоящие учителя всецело преданные своей работе, есть и в современном мире. А также можно понять, что некоторые ученики уже не видят в своих учителях того непререкаемого авторитета. Таким образом, если учитель имеет жалкий вид и воля его слаба, он не получит со стороны своих учеников никакого уважения.

Бин Синь в своем рассказе повествует историю о молодой учительнице, которая совсем недавно пришла преподавать в школу. На первом своем уроке ей пришлось пройти трудное испытание: ученики сначала с опаской и недоверием отнеслись к новому преподавателю, а, заметив на доске ошибку, и вовсе стали перешептываться за ее спиной. Молодая девушка, попадая в такую недружелюбную обстановку, проходит серьезное испытание. Но ей удается справиться при помощи своей чуткости, данной ей природой, ученики принимают новую учительницу.

Таким образом, продемонстрированные в трех рассказах случаи позволяют уяснить, насколько сильное изменение произошло в отношении учеников к своему педагогу с течением времени. Теперь авторитет учителя не настолько непоколебим как в древние времена, авторитет нужно заработать тяжким трудом над собой. А в случае возникновения непредвиденных ситуаций учителю приходится применять весь свой запас мудрости и таланта для урегулирования вопроса. Бесспорно, что такие изменения продолжались на протяжении множества веков, человеческие 
взаимоотношения изменялись раньше, и будут изменяться впредь. Отсюда можно сделать вывод, что интерес китайских писателей к теме взаимоотношений «учитель-ученик» не угаснет еще долгое время.

\section{СПИСОК ЛИТЕРАТУРЫ}

Чабанова, С. С. (2011) Авторитет учителя в историко-педагогической ретроспективе // Знание. Понимание. Умение. № 3. С. 275-278.

История Китая (2002) / под ред. А. В. Меликсетова. 2-е изд., испр. и доп. М. : Изд-во МГУ ; Изд-во «Высшая школа». 736 с.

Дата поступления: 12.12.2016 г.

Санникова Ольга Александровна - аспирант кафедры педагогики и психологии высшей школы Московского гуманитарного университета. Адрес: 111395, Россия, г. Москва, ул. Юности, д. 5. Тел.: +7 (499) 374-7459. Эл. адрес: sannikova.23@mail.ru. Научный руководитель - д-р пед. н., проф. Л. В. Романюк.

Sannikov Olga Alexandrovna, Postgraduate student of the Department of pedagogy and psychology of higher school, Moscow University for the Humanities. Postal address: 111395, Russia, Moscow, street Youth, d. 5. Tel.: +7 (499) 374-74-59. E-mail: sannikova.23@mail.ru. Scientific Director - Doctor of Pedagogy, Professor L. V. Romaniuk.

\section{Для цитирования:}

Санникова О.А. Авторитет учителя в китайской культурной традиции [Электронный ресурс] // Научные труды Московского гуманитарного университета. 2016, № 6. URL: http://journals.mosgu.ru/trudy/article/view/385 (дата обращения: дд.мм.гг.). 